\title{
Recognition Method of Mine Water Sources Based on Factor Analysis
}

\author{
Li Yue and Shi Longqing*
}

\author{
College of Earth Science and Engineering, Shandong University of Science and Technology, Qingdao \\ 266590, China
}

\begin{abstract}
Taking Jiaozuo mining area as the research background, according to the survey of water samples among the main water-filled aquifers of the mine and water gushing sources due to the exploitation of the No.2 ${ }_{1}$ coal seams in Shanxi group, six kinds of water chemical composition were selected as the sample indexes, including $\mathrm{Cl}, \mathrm{SO}_{4}{ }^{2-}, \mathrm{HCO}_{3}{ }^{-}, \mathrm{Na}^{+}+\mathrm{K}^{+}, \mathrm{Ca}^{2+}, \mathrm{Mg}^{2+}$, based on the data of groundwater chemical composition, and a principal component analysis was applied to establish the mathematical model by the method of factor analysis. A piper diagram was used to intuitively conduct the synthetical analyses for the general chemical characteristics and water quality types of the water samples. At the same time, via the comparative analysis between the water properties of water exits and that of the main aquifers in the Jiaozuo mining area, discrimination of the hybridization of the multiple water gushing sources due to coal mining was done. Moreover, by dint of the SPSS factor analysis, the water chemical proxies were carried on dimensionality reduction from the six kinds of water chemical composition to the three major factors, which replaced the original variables to participate in the data modeling. The results of the study showed that the combination of the piper diagram and the factor analysis modeling could effectively identify the water gushing sources owing to exploiting the No. $2_{1}$ coal seams of the Shanxi group in the Jiaozuo mining area and rank on the basis of the contributions of each aquifer to the amounts of water bursting in the mine, solving the problems of information superposition and correlations consisted in the identification of water gushing sources, which provides a theoretical basis for the prevention and cure of the mine water disasters.
\end{abstract}

Keywords: Mine water inrushes; Recognition of mine water sources; Piper diagram; Factor analysis.

\section{INTRODUCTION}

China is a country with coal as the major energy resource, and it is also a country with frequent mines water hazards. The proportions of coal consumption in the Chinese energy consumption structure have been about $65 \% \sim 70 \%$ for a long time. Although China is vigorously developing and using new energy, according to "the 13th Five-Year plan for energy development" [1] in 2016, and striving to decrease the proportions of coal consumption to about $58 \%$ by 2020 in China, it is forecasted that the consumption of coal in Chinese structure of energy consumption will still account for more than $50 \%$ even by 2050 . Therefore, coal will still be the major energy resource in our country for a long time. After mining more than half a century, the shallow coal resources have been almost exhausted, and most of the mines have entered deep mining in China, which intensifies the complexity of the geological and hydrogeological conditions, resulting in the frequent occurrence of mine water disasters and the diversity of types of mine gushing sources [2-7]. The deaths caused by coal mining in China are four times the total number of deaths among the major coal mining countries in the world from 2004 to 2010 [8-13]. Thirtyeight serious casualty accidents occurred in nationwide

*Address correspondence to this author at the College of Earth Science and Engineering, Shandong University of Science and Technology, Qingdao 266590, China; E-mail: cattony2002@163.com coal mining in 2008. Out of these, one incident that caused the death of more than ten people at a time; seven hundred and seven people died in it. The number of deaths caused by water inrush accidents reached one hundred and thirty-five people, accounting for $19.1 \%$ of the total number, which is next to the personal casualties caused by gas accidents [14-19]. According to the incomplete statistics based on related data, one hundred and eighty-two people died because of mining water hazards in China from 2013 to 2016. Therefore, it can be seen that the mining water hazards are the long-standing practical problems existing in the safety production of coal mining and need to be solved continuously [20-24].

How to monitor the water exits, distinguishing whether the known water sources and the water exits are connected, and the supplies of water sources for the yield of water exits is the basis for preventing and treating mining water hazards [25-30]. Currently, in the field of identifying water sources being from mine water gushing, the scholars have adopted different methods to distinguish the characteristics of the groundwater chemical composition and then predicted the types of water gushing sources [31-35]. For instance, Zhou et al. [36] proposed water-bursting source determination of a mine based on distance discriminant analysis model. Chen et al. [37-38] identified mine water inrush sources by Fisher's discriminant analysis method and 
Bayes' multi-group stepwise discriminant analysis theory. Yu et al. [39] applied the Fuzzy comprehensive evaluation method in identifying water sources of water-rush in the underground shaft. Jiang et al. [40] presented the particle swarm optimization support vectors machine method for identifying standard components of ions of groundwater. All of the above methods have achieved a certain guiding value to the fieldwork. However, because water bursting in mine is affected by various indicators such as climate, hydrological characteristics, and faulted structure of the mining area, the extraction of effective field data is relatively less [41-49]. When the evaluation index is multidimensional, there will be a problem of information superposition and relatively lesser data volume [50]. For example, although the literature [36] has well sorting performance, it is still a preliminary attempt to apply the theory to the identification and modeling of the mine water gushing sources, and there are still some problems to be further studied. The literature [40] has gained preferable results, but the prediction accuracy of LSSVM depends mainly on the selection of the penalty parameter $\mathrm{C}$ and the kernel function $\sigma$. So, it is a difficult problem needed to be resolved that how to accurately identify the situation of mine water gushing sources in the process of the working face in advance, in order to provide effective ways to prevent and control the water bursting in mine. In this study, we adopted the method based on the factor analysis, combining the practical engineering application of exploiting the No. $2_{1}$ coal seams of Shanxi group in the Jiaozuo mining area, using a piper diagram to roughly distinguish the hybridization of various water gushing sources. Based on full consideration of the six kinds of water chemical composition, we analyzed the relativity between the original variables and used SPSS factor analysis modeling to solve the core functions of each factor. And then solved the comprehensive scores of the influencing factors of the water gushing sources by the method of variable calculation and rank through the contributions of each aquifer to the water yield of mine inrushes, selecting the aquifers making greater contributions from the study results as the key protection targets of the water bursting in mine, and achieving the crucial significance of identifying the mine water gushing sources under limited information. Moreover, a living example proved by the cluster analysis of the known water samples of water exits showed that integrating the original variables into a few factors, which participate in data modeling instead of the original variables, preferably resolves the problems of information superposition and relativity between the evaluation indexes of water gushing sources. It is feasible to distinguish the mine water gushing sources by applying the multivariate statistical method of the factor analysis, and the discrimination is superior.

\section{MATERIALS AND METHODS}

Assume that the simple correlation coefficient matrix of the original variables is $R$

$$
R=\left[\begin{array}{cccc}
r_{11} & r_{12} & \cdots & r_{1 n} \\
r_{21} & r_{22} & \cdots & r_{2 n} \\
\mathrm{M} & \mathrm{M} & \mathrm{M} & \mathrm{M} \\
r_{n 1} & r_{n 2} & \cdots & r_{n n}
\end{array}\right]
$$

We conducted a study of the correlation between the original variables using the $\mathrm{KMO}$ inspection method [51]. If $K M O \geq 0.8$, there is strong relativity between the original variables. So, the original variables are suitable for factor analysis. Assuming that the number of the original variables is $p$, we can define them as $x_{1}, x_{2}, x_{3}, \Lambda, x_{p}$. Each of the original variables is expressed by the linear combination of the $k(k<p)$ factors [51], such as $f_{1}, f_{2}, f_{3}, \Lambda, f_{k}$.

$$
\begin{aligned}
& x_{1}=a_{11} f_{1}+a_{12} f_{2}+a_{13} f_{3}+\cdots+a_{1 k} f_{k}+\varepsilon_{1} \\
& x_{2}=a_{21} f_{1}+a_{22} f_{2}+a_{23} f_{3}+\cdots+a_{2 k} f_{k}+\varepsilon_{2} \\
& \cdots \\
& x_{p}=a_{p 1} f_{1}+a_{p 2} f_{2}+a_{p 3} f_{3}+\cdots+a_{p k} f_{k}+\varepsilon_{p}
\end{aligned}
$$

Where $x_{i}$ is the original variable. $f_{i}$ is the principal component. $a_{i j}$ is the linearity coefficient. $\varepsilon_{i}$ is the constant.

Firstly, we standardized the $p$ original correlation variables $x_{i}$ and calculated the simple correlation coefficient matrix $R_{1}$ between the original variables. Besides, gain the eigenvalues $\lambda_{1}, \lambda_{2}, \lambda_{3}, \Lambda, \lambda_{p}$ of the correlation coefficient matrix $R_{1}$ and the unit eigenvectors $\mu_{1}, \mu_{2} \Lambda \mu_{p} \quad$ corresponding to the eigenvalues. Moreover, via the coordinate conversion, the $p$ standardized original correlation variable $x_{i}$ is carried on the linear combination, transforming a group of uncorrelated variables $y_{i}$ [51]. The results are as follows:

$$
\begin{aligned}
& y_{1}=\mu_{11} x_{1}+\mu_{12} x_{2}+\mu_{13} x_{3}+\cdots+\mu_{1 p} x_{p} \\
& y_{2}=\mu_{21} x_{1}+\mu_{22} x_{2}+\mu_{23} x_{3}+\cdots+\mu_{2 p} x_{p} \\
& \cdots \\
& y_{p}=\mu_{p 1} x_{1}+\mu_{p 2} x_{2}+\mu_{p 3} x_{3}+\cdots+\mu_{p p} x_{p}
\end{aligned}
$$

Where $y_{i}$ is the uncorrelated variable. $\mu_{i j}$ is the unit eigenvector. $x_{i}$ is the original variable. 
Obtain the factor loading matrix as follows [51]:

$$
A=\left[\begin{array}{rrrr}
a_{11} & a_{12} & \Lambda & a_{1 k} \\
a_{21} & a_{22} & \Lambda & a_{2 k} \\
\mathrm{M} & \mathrm{M} & & \mathrm{M} \\
a_{p 1} & a_{p 2} & \Lambda & a_{p p}
\end{array}\right]=\left[\begin{array}{cccc}
\mu_{11} \sqrt{\lambda_{1}} & \mu_{21} \sqrt{\lambda_{2}} & \Lambda & \mu_{k 1} \sqrt{\lambda_{k}} \\
\mu_{12} \sqrt{\lambda_{1}} & \mu_{22} \sqrt{\lambda_{2}} & \Lambda & \mu_{k 2} \sqrt{\lambda_{k}} \\
\mathrm{M} & \mathrm{M} & & \mathrm{M} \\
\mu_{1 p} \sqrt{\lambda_{1}} & \mu_{2 p} \sqrt{\lambda_{2}} & \Lambda & \mu_{k p} \sqrt{\lambda_{k}}
\end{array}\right]
$$

Determine the number of factors, supposing it is $k$, according to the accumulative variance contribution of the factors [51]. It is:

$$
a_{k}=\frac{\sum_{i=1}^{k} \lambda_{i}}{\sum_{i=1}^{p} \lambda_{i}}
$$

Where $a_{k}$ is the accumulative variance contribution. $\lambda_{i}$ is the eigenvalue. $k$ is the number of principal components. $p$ is the number of original variables.

Selecting $a_{k} \geq 0.85$, which means the quantity of the eigenvalues is equal to the number of the factors, and the mathematical model is established by factor analysis.

\section{Study Area}

The Jiaozuo mining area (Fig. 1) is located on the southern side of the uplift of the anticlinorium, situating in the composite area of the East-West structure and the Neocathaysian structural system. The major coalbearing series being in the Jiaozuo mining area is the Permo-Carboniferous coal seams. The No.2 ${ }_{1}$ coal seams in the Shanxi group, with an average of $6.0 \mathrm{~m}$ thickness of coal seams, were primarily exploited [52]. The major water-filled aquifers affecting the mine production in the study area mainly consist of the hydrated layer of quaternary system featured by sandgravel pore water, the Permian system aquifers featured by sand-shale crevice water, the carboniferous system aquifers featured by lamina carbonate crevicekarst water, and the Ordovician system aquifers featured by carbonatite karst water [53], but the aquicludes exist among the aquifers. However, there were thousands of water gushing caused by exploiting the No.2 1 coal seams of Shanxi group in the Jiaozuo mining area, where the critical discharge over $600 \mathrm{~m}^{3}$ per hour occurred 75 times, over $6000 \mathrm{~m}^{3}$ per hour occurred 8 times, and the maximum discharge of the mine water gushing is up to $1920 \mathrm{~m}^{3}$ per hour [52]. In order to ascertain the mine water gushing sources caused by exploiting the No.2 ${ }_{1}$ coal seams in the Shanxi group, the water sources, stemming from 32 sampling sites and 4 water exits, including the hydrated layer of the quaternary system, the roof sandstone aquifers, and the underlying aquifers mainly containing the Ordovician limestone formation and the Carboniferous limestone formation, were sampled to carry on detection. On the basis of the observed prototype data, six kinds of ion compositions with a distinct meaning $\mathrm{Cl}^{-} 、 \mathrm{SO}_{4}^{2-} 、 \mathrm{HCO}_{3}^{-} 、 \mathrm{Na}^{+}+\mathrm{K}^{+} 、 \mathrm{Ca}^{2+} 、 \mathrm{Mg}^{2+}$, were selected as the chemical characteristics of the different water sources. Table 1 shows the content of ion composition detected in the 32 water samples of the aquifers [53]. Table 2 shows the content of ion composition detected in the 4 water samples of the water exits [53].

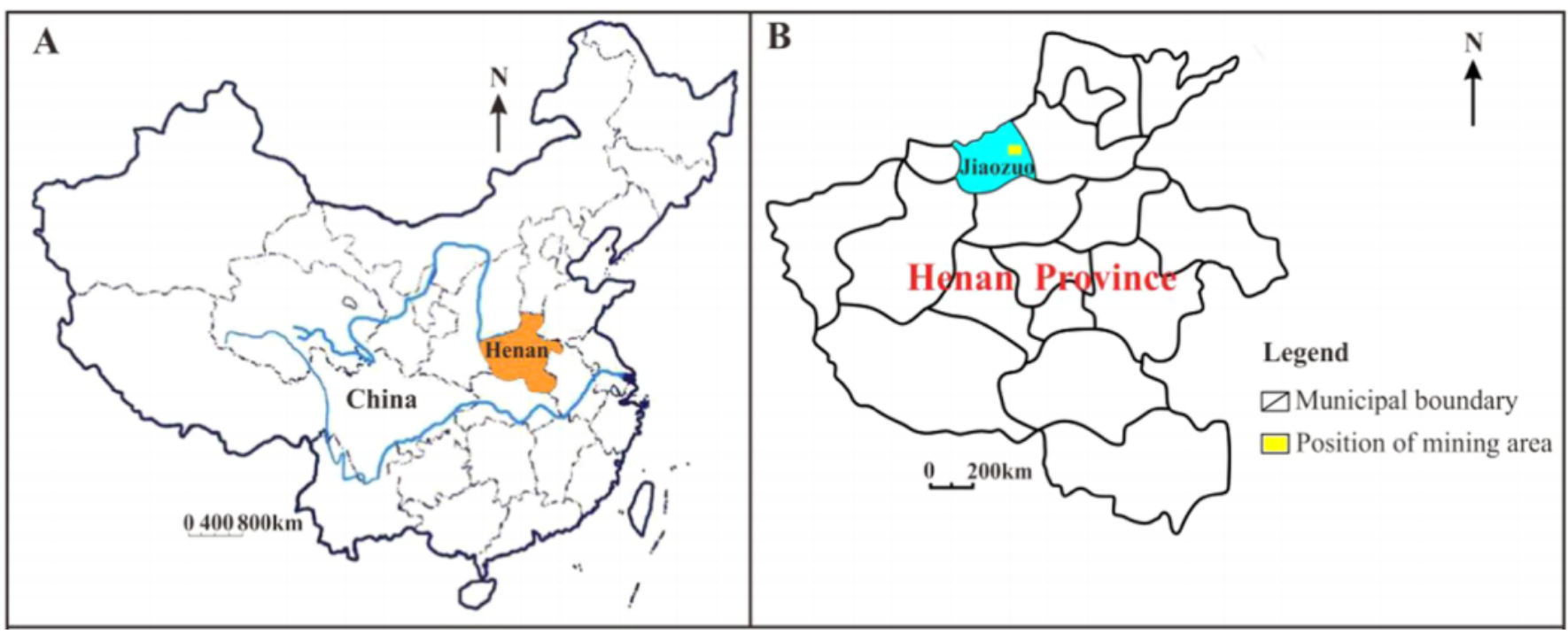

Figure 1: Location map of the Jiaozuo mining area. 
Table 1: The Content of Ion Composition Detected in the 32 Water Samples of the Aquifers

\begin{tabular}{|c|c|c|c|c|c|c|}
\hline The Sources of Water Samples & \multicolumn{6}{|c|}{ The Content of Ion Composition } \\
\hline The Ordovician limestone aquifers 1 & 76.15 & 15.56 & 11.98 & 292.84 & 26.90 & 8.50 \\
\hline The Ordovician limestone aquifers2 & 65.73 & 18.48 & 19.34 & 239.19 & 67.24 & 10.64 \\
\hline The Ordovician limestone aquifers3 & 84.57 & 24.81 & 11.50 & 253.83 & 82.61 & 19.86 \\
\hline The Ordovician limestone aquifers6 & 73.24 & 24.80 & 44.88 & 303.56 & 85.97 & 24.07 \\
\hline The Carboniferous limestone aquifers 1 & 61.23 & 29.33 & 10.29 & 309.85 & 47.46 & 12.16 \\
\hline The Carboniferous limestone aquifers2 & 59.30 & 28.40 & 10.64 & 291.68 & 34.70 & 12.59 \\
\hline The Carboniferous limestone aquifers3 & 69.30 & 26.39 & 8.00 & 295.24 & 43.88 & 10.96 \\
\hline The Carboniferous limestone aquifers6 & 63.00 & 24.70 & 7.10 & 266.13 & 37.80 & 7.35 \\
\hline The Carboniferous limestone aquifers7 & 67.10 & 39.00 & 7.70 & 281.57 & 46.50 & 8.82 \\
\hline The Carboniferous limestone aquifers8 & 68.70 & 24.90 & 7.00 & 282.16 & 43.77 & 11.70 \\
\hline The Carboniferous limestone aquifers9 & 62.96 & 17.28 & 17.85 & 284.57 & 23.31 & 6.68 \\
\hline The Carboniferous limestone aquifers 10 & 61.59 & 18.85 & 13.59 & 276.69 & 23.57 & 6.68 \\
\hline The Carboniferous limestone aquifers 11 & 63.87 & 32.83 & 10.00 & 295.87 & 65.09 & 4.06 \\
\hline The Carboniferous limestone aquifers 12 & 69.39 & 29.38 & 12.69 & 325.08 & 34.54 & 13.64 \\
\hline The roof sandstone aquifers 1 & 3.10 & 1.10 & 98.10 & 638.70 & 43.84 & 23.50 \\
\hline Hydrated layer of quaternary system2 & 99.20 & 31.10 & 13.25 & 361.12 & 83.00 & 29.85 \\
\hline Hydrated layer of quaternary system 3 & 106.7 & 39.10 & 9.20 & 402.10 & 69.80 & 40.10 \\
\hline Hydrated layer of quaternary system 4 & 98.20 & 20.60 & 17.30 & 354.40 & 53.20 & 20.24 \\
\hline Hydrated layer of quaternary system 5 & 69.14 & 22.93 & 4.68 & 251.26 & 13.38 & 26.67 \\
\hline Hydrated layer of quaternary system 6 & 74.67 & 16.92 & 19.58 & 272.94 & 27.62 & 24.46 \\
\hline Hydrated layer of quaternary system7 & 70.47 & 16.78 & 19.90 & 294.47 & 10.79 & 18.40 \\
\hline Hydrated layer of quaternary system 8 & 51.73 & 16.04 & 20.54 & 236.00 & 12.34 & 24.34 \\
\hline
\end{tabular}

Table 2: The Content of Ion Composition Detected in the 4 Water Samples of the Water Exits

\begin{tabular}{|c|c|c|c|c|c|c|}
\hline \multirow{2}{*}{ The Sources of Water Samples } & \multicolumn{5}{|c|}{ The Content of lon Composition } \\
\cline { 2 - 7 } & $\mathbf{C a}^{2+}$ & $\mathbf{M g}^{2+}$ & $\mathbf{N a}^{+}+\boldsymbol{K}^{+}$ & $\mathbf{H C O}_{3}{ }^{-}$ & $\mathbf{S O}_{4}{ }^{2-}$ & $\mathbf{C r}$ \\
\hline \hline Water exit 1 & 66.40 & 19.59 & 23.76 & 255.29 & 57.26 & 18.13 \\
\hline Water exit 2 & 64.45 & 26.84 & 9.97 & 288.14 & 40.53 & 9.59 \\
\hline Water exit 3 & 8.93 & 3.63 & 294.75 & 680.51 & 24.24 & 30.27 \\
\hline Water exit 4 & 81.96 & 24.41 & 14.19 & 315.08 & 40.99 & 25.81 \\
\hline
\end{tabular}




\section{RESULTS}

\section{Distribution Characteristics of Mine Water Quality}

Piper diagram is an analytic procedure in common use to determine the hydrochemistry ion composition, which can be used to intuitively analyze the general chemical characteristics and the types of water quality among the water sources [54-59]. In this study, based on the six ion compositions with a distinct meaning, $\mathrm{Cl}^{-} 、 \mathrm{SO}_{4}^{2-} 、 \mathrm{HCO}_{3}^{-} 、 \mathrm{Na}^{+}+\mathrm{K}^{+} 、 \mathrm{Ca}^{2+} 、 \mathrm{Mg}^{2+}$, extracted from the 32 sampling sites and 4 water exits, adopting hydrochemistry software AqQA, we analyzed the distribution characteristics of water quality among the water samples of the main aquifers and water exits in Jiaozuo mining area. Meanwhile, through the comparison of hydrochemistry composition and hydrochemistry content among the water samples, the possible water gushing sources were distinguished, which were caused by exploiting the No. $2_{1}$ coal seams in the Shanxi group. The results are shown in Fig. 2.

It can be seen from the figure that the water samples of the overlying aquifers and the underlying aquifers are all concentrated in the rhombic area, respectively, belonging to $\mathrm{HCO}_{3}^{-}-\mathrm{Na}^{+}+\mathrm{K}^{+}$and $\mathrm{HCO}_{3}^{-}-$ $\mathrm{Ca}^{2+}$. The water samples of the water exits are basically located in the third area of the rhombic basin, where the content of weak chloroplatinate ion is greater than that of strong acid ion, meaning that the content of $\mathrm{HCO}_{3}{ }^{-}$is greater than that of $\mathrm{SO}_{4}{ }^{2-}$ and $\mathrm{Cl}$, so the type of water quality belongs to $\mathrm{HCO}_{3}^{-}-\mathrm{Ca}^{2+} \cdot \mathrm{Na}^{+}+\mathrm{K}^{+}$. And there are four water samples of the water exits, staggered among the distribution range of the roof sandstone aquifers and the floor limestone aquifers, reflecting that the water quality of the coal measures rushing is close to that of the overlying and underlying aquifers. It means that the water yield caused by exploiting the No. $2_{1}$ coal seams of the Shanxi group in the Jiaozuo mining area is jointly supplied by the overlying and underlying aquifers.

\section{Variable Correlation Analysis}

The strong correlation between the original variables is an essential prerequisite for the extraction of public factors and the factor analysis [51]. So, this paper carries out the correlation analysis among the original variables with the help of the method of $K M O$ inspection. The results of the analysis are shown in Table 3.

Table 3: The Results of the KMO and Bartlett Inspection

\begin{tabular}{|c|c|}
\hline $\begin{array}{c}\text { Kaiser-Meyer-Olkin Measure with } \\
\text { Adequate Sampling }\end{array}$ & $\mathbf{0 . 8 0 5}$ \\
\hline \hline $\begin{array}{c}\text { The sophericity test of Bartlett Approximate } \\
\text { chi square distribution }\end{array}$ & 168.985 \\
\hline$d f$ & 15 \\
\hline Sig. & 0.000 \\
\hline
\end{tabular}

As seen from Table 3, the observed value of the sphericity test of Bartlett statistic is 168.985 , and its corresponding probability value $P$ is less than the given
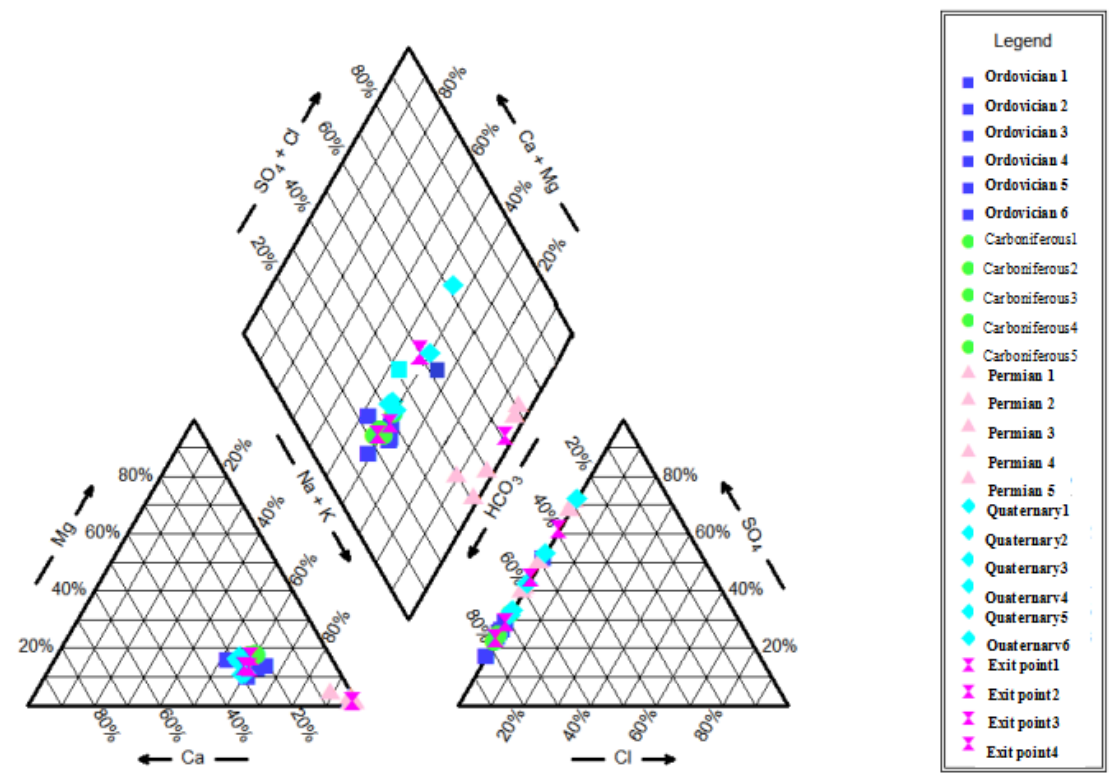

Figure 2: Piper diagram. 
significance level. In addition, the result of the KaiserMeyer-Olkin measure is 0.805 . According to the comparison between the above-mentioned analysis results and the modules, we can conclude that the original variables are suited for factor analysis.

Modeling for the Recognition of Mine Water Gushing Sources Based on the SPSS Factor Analysis

According to the correlation coefficient matrix of the original variables, adopting the method of the principal component analysis specifies three factors to be extracted, and the initial solution is obtained. The analysis results are shown in Table 4 to 6 .

Table 4: The Common Factor Variances

\begin{tabular}{|c|c|c|}
\hline & Initial Value & Extraction \\
\hline \hline $\mathrm{Ca}^{2+}$ & 1.000 & 0.918 \\
\hline $\mathrm{Mg}^{2+}$ & 1.000 & 0.818 \\
\hline $\mathrm{Na}^{+}+\mathrm{K}^{+}$ & 1.000 & 0.936 \\
\hline $\mathrm{HCO}_{3}{ }^{-}$ & 1.000 & 0.889 \\
\hline $\mathrm{SO}_{4}{ }^{2-}$ & 1.000 & 0.981 \\
\hline $\mathrm{Cr}$ & 1.000 & 0.979 \\
\hline
\end{tabular}

As seen from the extraction results, in the case of specifying three eigenvalues to be extracted, the communalities between all the original variables have a higher level, and the cumulative contribution of variances can account for $100 \%$. The three factors explain $92.014 \%$ of the total square deviation among the original variables. It can be seen from the scree graph (Fig. 3) that the first factor has a higher eigenvalue, making a greater contribution to interpreting the original variables. Therefore, the total effect of the factor extraction is satisfactory in this study. The factor analytic modeling is shown as follows:
$\mathrm{Na}^{+}+\mathrm{K}^{+}=0.952 f_{1}+0.145 f_{2}-0.090 f_{3} ; \quad \mathrm{HCO}_{3}^{-}=0.909 f_{1}+0.227 f_{2}-0.109 f_{3}$ $\mathrm{Ca}^{2+}=-0.898 f_{1}+0.205 f_{2}+0.263 f_{3} ; \quad M g^{2+}=-0.877 f_{1}+0.209 f_{2}+0.071 f_{3}$ $\mathrm{Cl}^{-}=0.614 f_{1}+0.609 f_{2}+0.480 f_{3} ; \quad S_{4}^{2-}=-0.453 f_{1}+0.777 f_{2}-0.416 f_{3}$

where $f_{i}$ is the principal component.

Table 6: The Component Matrix

\begin{tabular}{|c|c|c|c|}
\hline & \multicolumn{3}{|c|}{ Composition } \\
\cline { 2 - 4 } & $\mathbf{1}$ & $\mathbf{2}$ & $\mathbf{3}$ \\
\hline \hline $\mathrm{Na}^{+}+\mathrm{K}^{+}$ & 0.952 & 0.145 & -0.090 \\
\hline $\mathrm{HCO}_{3}{ }^{-}$ & 0.909 & 0.227 & -0.109 \\
\hline $\mathrm{Ca}^{2+}$ & -0.898 & 0.205 & 0.263 \\
\hline $\mathrm{Mg}^{2+}$ & -0.877 & 0.209 & 0.071 \\
\hline $\mathrm{Cr}$ & 0.614 & 0.609 & 0.480 \\
\hline $\mathrm{SO}_{4}{ }^{2-}$ & -0.453 & 0.777 & -0.416 \\
\hline
\end{tabular}

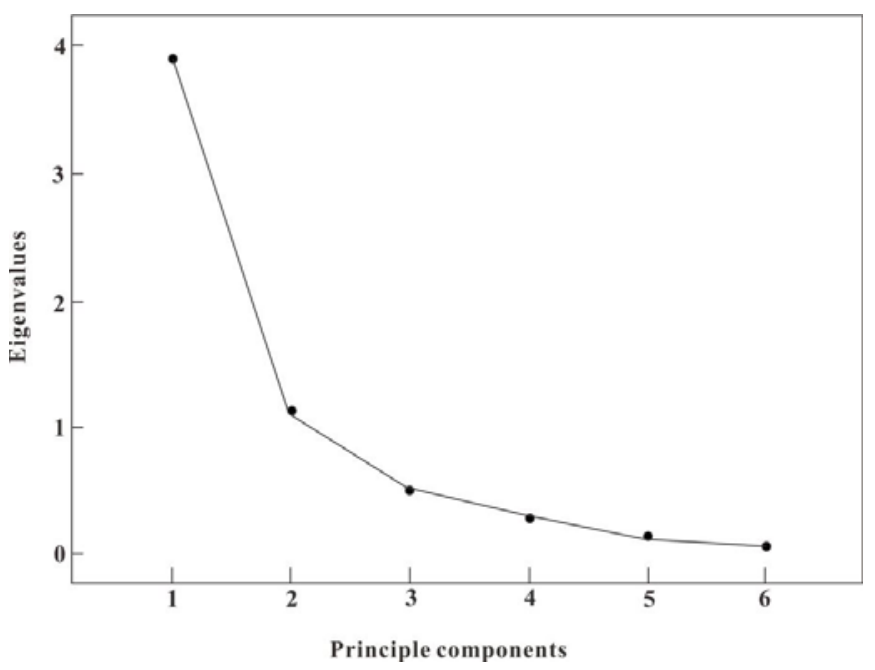

Figure 3: The Scree Graph of Factor Analysis.

The five variables present higher loading on the first factor. So adopting the method of varimax conducts the orthogonal rotation for the factor loading matrix

Table 5: Total Variances of Interpretation

\begin{tabular}{|c|c|c|c|c|c|c|}
\hline \multirow{2}{*}{$\begin{array}{c}\text { Ingredient } \\
\text { S }\end{array}$} & \multicolumn{2}{|c|}{ Initial Eigenvalues } & \multicolumn{2}{c|}{ Extraction of Sum of Squares } & \multicolumn{2}{c|}{ Rotation of Sum of Squares } \\
\cline { 2 - 7 } & Variances\% & Accumulation\% & Variances\% & Accumulation\% & Variances\% & Accumulation\% \\
\hline \hline 1 & 64.841 & 64.841 & 64.841 & 64.841 & 50.748 & 50.748 \\
\hline 2 & 18.880 & 83.721 & 18.880 & 83.721 & 22.011 & 72.760 \\
\hline 3 & 8.293 & 92.014 & 8.293 & 92.014 & & \\
\hline 4 & 4.674 & 96.688 & & & & \\
\hline 5 & 2.272 & 98.960 & & & & \\
\hline 6 & 1.040 & 100.000 & & & & \\
\hline
\end{tabular}


according to the descending order of the first-factor loading, as shown in Table 7, Table 8, and Fig. 4.

Table 7: The Rotational Component Matrix

\begin{tabular}{|c|c|c|c|}
\hline & \multicolumn{3}{|c|}{ Composition } \\
\cline { 2 - 4 } & $\mathbf{1}$ & $\mathbf{2}$ & $\mathbf{3}$ \\
\hline \hline $\mathrm{Ca}^{2+}$ & -0.918 & -0.066 & 0.266 \\
\hline $\mathrm{Na}^{+}+\mathrm{K}^{+}$ & 0.863 & 0.423 & -0.109 \\
\hline $\mathrm{HCO}_{3}{ }^{-}$ & 0.832 & 0.444 & -0.022 \\
\hline $\mathrm{Mg}^{2+}$ & -0.804 & -0.181 & 0.372 \\
\hline $\mathrm{Cr}$ & 0.267 & 0.952 & 0.026 \\
\hline $\mathrm{SO}_{4}{ }^{2-}$ & -0.219 & 0.030 & 0.966 \\
\hline Factor contributions & $50.748 \%$ & $22.012 \%$ & $19.254 \%$ \\
\hline
\end{tabular}

Table 8: The Component Transition Matrix

\begin{tabular}{|c|c|c|c|}
\hline Composition & $\mathbf{1}$ & $\mathbf{2}$ & $\mathbf{3}$ \\
\hline \hline 1 & 0.866 & 0.410 & -0.285 \\
\hline 2 & -0.043 & 0.630 & 0.775 \\
\hline 3 & -0.498 & 0.659 & -0.564 \\
\hline
\end{tabular}

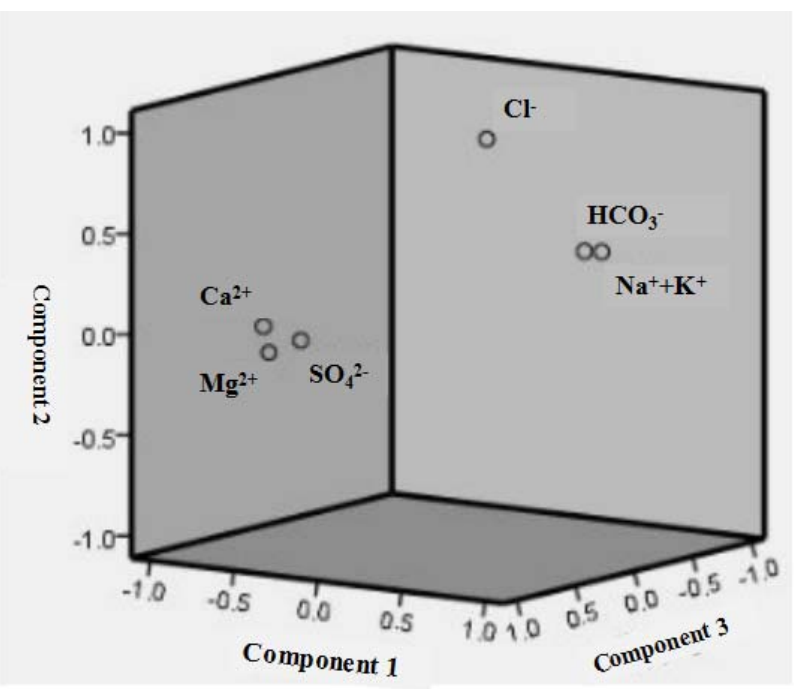

Figure 4: The Load Intensity Diagram of the Rotated Factors.

Via the orthogonal rotation, the first-factor loading accounts for $50.748 \%$, and the water-quality indexes closely connected with the first principal factor contain $\mathrm{Na}^{+}+\mathrm{K}^{+}, \mathrm{HCO}_{3}^{-}, \mathrm{Mg}^{2+}, \mathrm{Ca}^{2+}$. The second factor loading accounts for $22.012 \%$, and the water-quality index closely connected with the second principal factor is $\mathrm{Cr}$. The third factor loading accounts for $19.254 \%$, and the water-quality index closely connected with the third principal factor is $\mathrm{SO}_{4}{ }^{2-}$. Owing to the contribution rate of the first principal factor is greater than that of other principal factors, as shown in Table 9, there is no linear correlation among the three factors. So, the key impacting indicators of the mine water gushing sources caused by exploiting the No.2 1 coal seams of Shanxi group in the Jiaozuo mining area include $\mathrm{Na}^{+}+\mathrm{K}^{+}, \mathrm{HCO}_{3}^{-}, \mathrm{Mg}^{2+}, \mathrm{Ca}^{2+}$. So using the regression method estimates the factor score coefficient as seen from Table 10. The factor score functions are as follows:

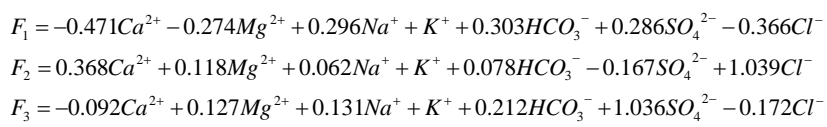

Where $F_{i}$ is the factor score.

Table 9: The Component Score Covariance Matrix

\begin{tabular}{|c|c|c|c|}
\hline Composition & $\mathbf{1}$ & $\mathbf{2}$ & $\mathbf{3}$ \\
\hline \hline 1 & 1.000 & 0.000 & 0.000 \\
\hline 2 & 0.000 & 1.000 & 0.000 \\
\hline 3 & 0.000 & 0.000 & 1.000 \\
\hline
\end{tabular}

Table 10: The Component Score Coefficient Matrix

\begin{tabular}{|c|c|c|c|}
\hline \multirow{2}{*}{} & \multicolumn{3}{|c|}{ Composition } \\
\cline { 2 - 4 } & $\mathbf{1}$ & $\mathbf{2}$ & $\mathbf{3}$ \\
\hline \hline $\mathrm{Ca}^{2+}$ & -0.471 & 0.368 & -0.092 \\
\hline $\mathrm{Mg}^{2+}$ & -0.274 & 0.118 & 0.127 \\
\hline $\mathrm{Na}^{+}+\mathrm{K}^{+}$ & 0.296 & 0.062 & 0.131 \\
\hline $\mathrm{HCO}_{3}{ }^{-}$ & 0.303 & 0.078 & 0.212 \\
\hline $\mathrm{SO}_{4}{ }^{2-}$ & 0.286 & -0.167 & 1.036 \\
\hline $\mathrm{Cr}$ & -0.366 & 1.039 & -0.172 \\
\hline
\end{tabular}

\section{DISCUSSION}

\section{Recognition of Mine Water Gushing Sources Caused by Exploiting the No.2 ${ }_{1}$ Coal Seams of Shanxi Group in the Jiaozuo Mining Area}

Using the factor score functions obtained above, we can calculate the scores that the water samples from various water-bearing strata obtain on the different factors. Select the top ten rankings as shown in Table 11.

On the basis of comprehensive factor analysis modeling to construct the evaluating pattern solve the synthesis scores of the key influencing factors for the 
Table 11: Scoring and Ranking of the Principal Factors

\begin{tabular}{|c|c|c|c|c|c|c|}
\hline Aquifers & \multicolumn{2}{|c|}{$F_{1}$} & \multicolumn{2}{|c|}{$F_{2}$} & \multicolumn{2}{|c|}{$F_{3}$} \\
\hline The roof sandstone aquifers 1 & 227.646 & 5 & 72.72 & 10 & 198.117 & 5 \\
\hline The roof sandstone aquifers 2 & 217.75 & 6 & 87.323 & 6 & 195.633 & 6 \\
\hline The roof sandstone aquifers 3 & 303.792 & 3 & 115.525 & 2 & 221.477 & 3 \\
\hline The roof sandstone aquifers 6 & 304.219 & 2 & 113.828 & 3 & 211.837 & 4 \\
\hline The Ordovician limestone aquifers 3 & 50.954 & 28 & 59.065 & 18 & 136.626 & 10 \\
\hline The Ordovician limestone aquifers 6 & 80.982 & 7 & 64.522 & 15 & 155.47 & 8 \\
\hline Hydrated layer of quaternary system 1 & 69.073 & 13 & 73.602 & 9 & 132.861 & 12 \\
\hline Hydrated layer of quaternary system 4 & 70.015 & 12 & 76.476 & 8 & 127.974 & 13 \\
\hline The Carboniferous limestone aquifers 1 & 70.78 & 10 & 53.153 & 23 & 116.656 & 15 \\
\hline The Carboniferous limestone aquifers 11 & 71.88 & 9 & 42.186 & 32 & 133.603 & 11 \\
\hline
\end{tabular}

Table12: The Scoring and Ranking of the Multi-Stress

\begin{tabular}{|c|c|c|c|c|c|}
\hline $\boldsymbol{F}$ & Scores & Rank & $\boldsymbol{F}$ & Scores & Rank \\
\hline The roof sandstone aquifers 3 & 231.5787 & 2 & The Carboniferous limestone aquifers 5 & 67.2188 & 18 \\
\hline The roof sandstone aquifers 6 & 229.08026 & 3 & The Ordovician limestone aquifers 2 & 66.9025 & 19 \\
\hline The roof sandstone aquifers 5 & 217.80654 & 4 & The Carboniferous limestone aquifers 8 & 66.20584 & 20 \\
\hline Hydrated layer of quaternary system 3 & 94.97373 & 7 & The Ordovician limestone aquifers 1 & 63.37892 & 23 \\
\hline Hydrated layer of quaternary system 2 & 92.19889 & 8 & The Carboniferous limestone aquifers 4 & 62.61554 & 24 \\
\hline The Ordovician limestone aquifers 6 & 91.48338 & 9 & The Carboniferous limestone aquifers 6 & 61.2348 & 25 \\
\hline Hydrated layer of quaternary system 1 & 82.67795 & 10 & Hydrated layer of quaternary system 7 & 61.20247 & 26 \\
\hline The Carboniferous limestone aquifers 1 & 75.00508 & 13 & The Ordovician limestone aquifers 5 & 60.50413 & 29 \\
\hline The Carboniferous limestone aquifers 12 & 73.44 & 14 & The Ordovician limestone aquifers 4 & 58.43372 & 30 \\
\hline The Ordovician limestone aquifers 3 & 70.80702 & 15 & Hydrated layer of quaternary system 8 & 51.73281 & 31 \\
\hline The Carboniferous limestone aquifers 3 & 68.90218 & 16 & Hydrated layer of quaternary system 5 & 49.04206 & 32 \\
\hline
\end{tabular}

mine water gushing sources. The results of the reckoning are shown in Table 12.

As seen from Table 12, thirty-two water samples of the aquifers were generally ranked from high to low according to the scores. It means that the principal sources of mine water inrushes caused by exploiting the No. $2_{1}$ coal seams of the Shanxi group in the Jiaozuo mining area are the roof sandstone aquifers [60-70], followed by the floor limestone aquifers and the hydrated layer of the quaternary system [71-79]. In order to further illustrate the situation of mine water inrushes with the working face advanced during the process of exploitation in the Jiaozuo mining area, we 


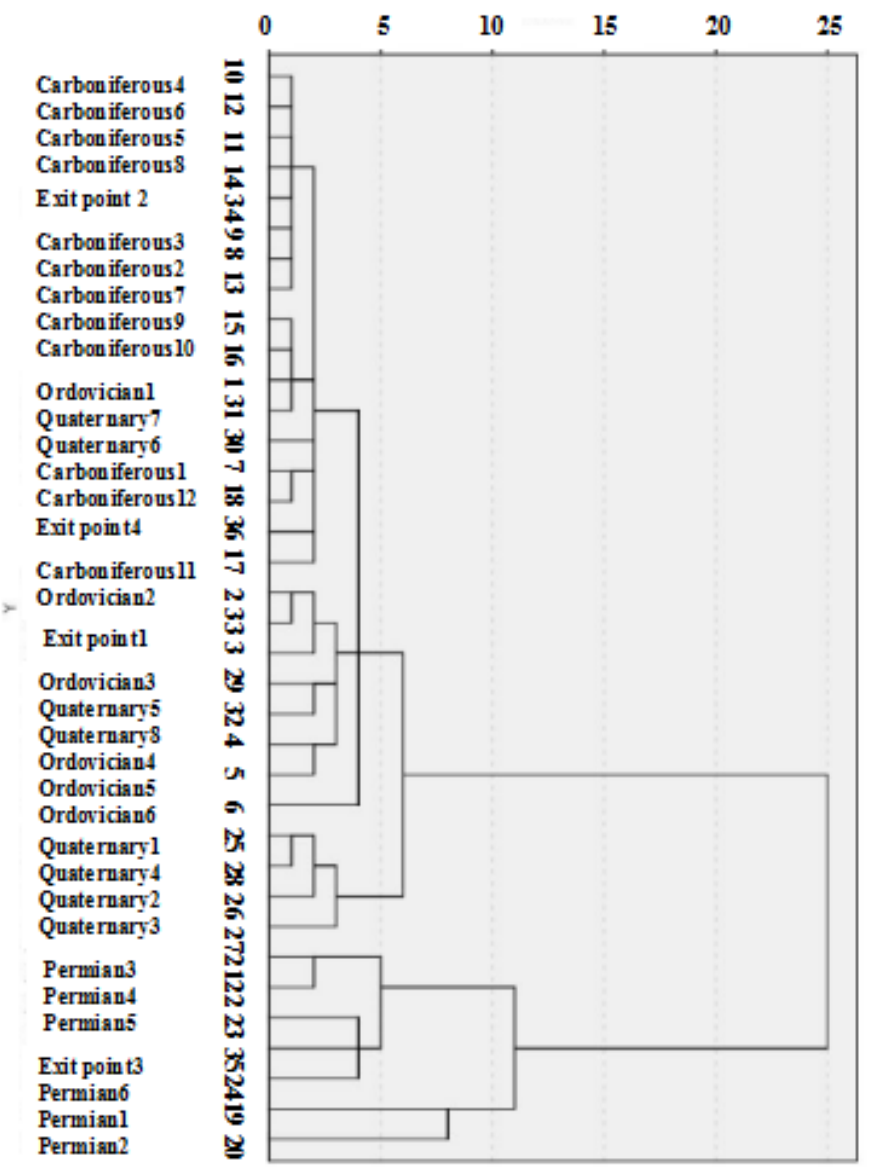

Figure 5: The dendrograms of hierarchical clustering.

adopted the analytic procedure of hierarchical clustering to carry on the discrimination and classification of the mine water gushing sources for the four detected water exits. The recognized results are shown in Fig. $\mathbf{5 .}$ From the chart, we can find out that the mine water bursting sources of the four known water exits come from the Ordovician limestone aquifers 2, several Carboniferous limestone aquifers, the roof sandstone aquifers 3 , and several Carboniferous limestone aquifers, respectively. Therefore, when mining coal seams in the Jiaozuo mining area, we should make the roof sandstone aquifers and the floor limestone aquifers acquiring the higher comprehensive factor scores as the key point of monitoring, preventing the occurrence of mining water hazards [80-89].

\section{CONCLUSIONS}

1) In the case of mine water inrushes from the multiple water sources, recognizing the mine water gushing sources and distinguishing the contribution proportions of water gushing sources has an important directive function for preventing and curing the mining water hazards. In this paper, factor analytic modeling is applied to discriminating the sources of water bursting in mine. Based on the data of groundwater chemical composition, a model was established to recognize the gushing water sources, combining the practical application of discriminating the water gushing sources caused by exploiting the No.2 ${ }_{1}$ coal seams of the Shanxi group in the Jiaozuo mining area to prove the applicability and scientificalness of the model.

2) Based on the analysis results of the piper diagram and the SPSS factor modeling, the main gushing water sources caused by exploiting the No.2 coal seams of the Shanxi group in the Jiaozuo mining area are the roof sandstone aquifers, followed by the floor limestone aquifers and the hydrated layer of the quaternary system.

\section{ACKNOWLEDGMENTS}

The authors thank the editors and two anonymous reviewers for their careful work and thoughtful suggestions. We gratefully acknowledge the financial support of the National Natural Science Foundation of China (41807283) and (51804184). 


\section{REFERENCES}

[1] The National Development and Reform Commission, the National Energy Administration. The 13th Five-Year plan for energy development. 2016.

[2] Yang Q, Han DX. China coal geology. China Coal Industry Publishing House, Beijing. 1979.

[3] Qu XY, Qiu M, Liu JH, Niu ZC, Wu XS. Prediction of maximal water bursting discharge from coal seam floor based on multiple nonlinear regression analysis. Arabian Journal of Geosciences 2019; 12(18): 567.

https://doi.org/10.1007/s12517-019-4748-7

[4] Shi LQ, Qu XY, Han J, Qu M, Gao WF, Qin DX, Liu HS. Multi-model fusion for assessing the risk of the inrush of limestone karst water through the mine floor. Journal of China Coal Society 2019; 44(8): 2484-2493.

[5] Shi LQ, Qiu M, Wang Y, Qu XY, Liu TH. Evaluation of water inrush from underlying aquifers by using a modified waterinrush coefficient model and water-inrush index model: a case study in Feicheng coalfield, China. Hydrogeol J 2019; 27: 2105-2119. https://doi.org/10.1007/s10040-019-01985-2

[6] Chiara C, Sabrina B, Cesare C. GPR surveys for the prevention of karst risk in underground gypsum quarries. Tunnelling and Underground Space Technology 2020; 95: 103137.

https://doi.org/10.1016/i.tust.2019.103137

[7] Zhao TC. Comprehensive control technology of Ordovician limestone water in North China. China Coal Industry Publishing House. 2006.

[8] The State Statistical Bureau. The output of raw coal in China increased by $0.8 \%$ in 2013. China Coal 2014; (3): 115.

[9] Li B, Chen YL. Risk assessment of coal floor water inrush from underlying aquifers based on GRA-AHP and its application. Geotechnical and Geological Engineering 2016; 34(1): 143-154. https://doi.org/10.1007/s10706-015-9935-z

[10] Xiao L, Tang SH, Zhao CL, Yuan TX, Yang W. Grey-risk estimation of the water inrush from No. 9 coal floor in Guoerzhuang Mine. Applied Mechanics and Materials 2013; 295-298: 3019-3022.

https://doi.org/10.4028/www.scientific.net/AMM.295-298.3019

[11] Liu WT, Liu SL, Sun YS. Risk evaluation of water inrush from coal floor based on BP neural network. Applied Mechanics and Materials 2015; 744-746: 1728-1732.

https://doi.org/10.4028/www.scientific.net/AMM.744-746.1728

[12] Shi LQ, Qiu M, Wang $Y$, Qu XY, Liu TH. Evaluation of water inrush from underlying aquifers by using a modified waterinrush coefficient model and water-inrush index model: a case study in Feicheng Coalfield, China. Hydrogeology Journal 2019; 27: 2105-2119.

https://doi.org/10.1007/s10040-019-01985-2

[13] Shi LQ, Han J, Song Y. Forecast of water inrush from mining floor with probability indexes. Journal of China University of Mining \& Technology (Social Science) 1999; 28(5): 442-460.

[14] Shi LQ, Han J. Water-inrush mechanism and prediction of coalbed floor. China University of Mining and Technology Press, Xuzhou. 2004.

[15] Wu Q, Zhang ZL, Ma JF. A new practical methodology of the coal floor water bursting to evaluate the master controlling index system construction. Journal of China Coal Society 2007; 32(1): 42-47.

[16] Wu Q, Zhang ZL, Zhang SY, Ma JF. A new practical methodology of the coal floor water bursting evaluating-the vulnerable index method. Journal of China Coal Society 2007; 32(11): 1121-1126.

[17] Qiu M, Shi LQ, Teng C, Zhou Y. Assessment of water inrush risk using the Fuzzy Delphi Analytic Hierarchy Process and
Grey Relational Analysis in the Liangzhuang Coal Mine, China. Mine Water Environ 2017; 36: 39-50.

https://doi.org/10.1007/s10230-016-0391-7

[18] Zhu ZK, Xu ZM, Sun YJ, Huang XL. Research on the risk evaluation methods of water inrush from coal floor based on dimensionless multi-source information fusion technique. Journal of Mining and Safety Engineering 2013; 30(6): 911916.

[19] Zhang WQ, Zhang GP, Li W, Hua X. A model of Fisher's discriminant analysis for evaluating water inrush risk from coal seam floor. Journal of China Coal Society 2013; 38(10): 1831-1836.

[20] Wu Q, Wang JH, Liu DH, Cui FP, Liu SQ. A new practical methodology of the coal floor water bursting evaluating IV: the application of AHP vulnerable index method based on GIS. J China Coal Soc 2009; 34: 233-238.

[21] Shi LQ, Han J. Floor water-inrush mechanism and prediction. China University of Mining and Technology Press, Xuzhou. 2004.

[22] Yu XG. Study on the broken depth of the damaged floor. Shandong University of Science and Technology. 2011.

[23] Shi LQ, Bo CS, Wei JC, Han J, Zhai MH, Zhai PH, Sang HX, Zhu L. Theory and technology of Ordovician limestone karst water control in North China type coalfield. China Coal Industry Publishing House, Beijing. 2015.

[24] Hu SQ. Analysis of water inrush hazard and water flooding in A group of coal mine in liuzhuang coal mine. Chengdu University of Technology. 2018.

[25] Wei WX, Lu XM, Shi LQ. Identification method of a multiwater source of mine water inrush. Journal of China Coal Society 2010; 35(05): 811-815.

[26] Yin SX. Modes and mechanism for water inrushes from coal seam floor. Journal of Xi'an University of Science and Technology 2009; 29(6): 661-665.

[27] Han J, Shi LQ, Yu XG, Wei JC, Li SC. Mechanism of mine water-inrush through a fault from the floor. Mining Science and Technology (China) 2009; 19: 276-281. https://doi.org/10.1016/S1674-5264(09)60052-1

[28] Barmaki MD, Rezaei M, Madadi S. Use of fractal dimensions analysis in geographic information system and remote sensing techniques to identify prospective groundwater zones in the Anar-Dashtegol anticline, Iran. Carbonates and Evaporites 2019; 35(1).

https://doi.org/10.1007/s13146-019-00535-x

[29] Guo XS, Shi LQ. Research on quantitative analysis of water inrush through risk based on fault impact factor and fault fractal dimension characteristics. Journal of Shandong University (Engineering Science) 2014; 44(05): 58-64.

[30] Wang G, Wu MM, Wang $R, X u H$, Song $X$. Height of the mining-induced fractured zone above a coal face. Eng Geol 2017; 216: 140-152. https://doi.org/10.1016/j.enggeo.2016.11.024

[31] Jaber JO, Mohsen MS. Evaluation of non-conventional water resources supply in Jordan-ScienceDirect. Desalination 2001; 136(1): 83-92. https://doi.org/10.1016/S0011-9164(01)00168-0

[32] Aykut T. Determination of groundwater potential zones using Geographical Information Systems (GIS) and Analytic Hierarchy Process (AHP) between Edirne-Kalkansogut (northwestern Turkey). Groundwater for Sustainable Development 2021; 12(12): 100545. https://doi.org/10.1016/i.gsd.2021.100545

[33] Gaur S, Chahar BR, Graillot D. Analytic elements method and particle swarm optimization based simulationoptimization model for groundwater management. Journal of Hydrology 2011; 402(3-4): 217-227.

https://doi.org/10.1016/j.jhydrol.2011.03.016 
[34] Drever JI. The geochemistry of natural waters: surface and groundwater environments. Journal of Environmental Quality 1997; 27(1): 245-246. https://doi.org/10.2134/jeq1998.00472425002700010037x

[35] Marios S. Interactions between groundwater and surface water: the state of the science. Hydrogeology Journal 2002; 10: 348.

https://doi.org/10.1007/s10040-002-0204-x

[36] Zhou J, Shi XZ, Wang HY. Water-bursting source determination of mine based on distance discriminant analysis model. Journal of China Coal Society 2010; 35(02): 278-282.

[37] Chen HJ, Li XB, Liu AH, Peng SQ. Identifying mine water inrush sources by Fisher discriminant analysis method. J. Cent. South Univ.(Natural Science) 2009; 40(04): 1114-1120.

[38] Chen HJ, Li XB, Liu AH. Studies of water source determination method of mine water inrush based on Bayes' multi-group stepwise discriminant analysis theory. The Rock and Soil Mechanics 2009; 30(12): 3655-3659.

[39] Yu KL, Yang YS, Zhang CP. Application of fuzzy comprehensive evaluation method in identifying water sources of water-inrush in the underground shaft. Met Min 2007; (03): 47-50.

[40] Jiang AN, Liang B.The particle swarm optimization support vectors machine method of identifying standard components of ions of groundwater. Journal of China Coal Society 2006; (03): 310-313.

[41] Rodell M, Velicogna I, Famiglietti JS. Satellite-based estimates of groundwater depletion in India. Nature 2009; 460(7258): 999-1002. https://doi.org/10.1038/nature08238

[42] Singhal DC, Israil M, Sharma VK, Kumar B. Evaluation of groundwater resource and estimation of its potential in Pathri Rao watershed, district Haridwar (Uttarakhand). Current Science 2010; 98(2): 162-170.

[43] Scanlon BR, Healy RW, Cook PG. Choosing appropriate techniques for quantifying groundwater recharge. Hydrogeology Journal 2002; 10(2): 347-347. https://doi.org/10.1007/s10040-002-0200-1

[44] Tóth J. A theoretical analysis of groundwater flow in small drainage basins. Journal of Geophysical Research 1963; 68(16): 4795-4812.

https://doi.org/10.1029/JZ068i016p04795

[45] Kamaraju MVV, Bhattacharya A, Sreenivasa Reddy G, Rao GC, Murthy GS, Rao TCM. Groundwater potential evaluation of West Godavari District, Andhra Pradesh State, India-a GIS approach. Ground Water 2010; 34(2): 318-325. https://doi.org/10.1111/j.1745-6584.1996.tb01891.x

[46] loka S, Onodera SI, Saito M, Rusydi A, Wakasa SA. Species and potential sources of phosphorus in groundwater in and around Mataram City, Lombok Island, Indonesia. SN Applied Sciences 2021; 3(1). https://doi.org/10.1007/s42452-020-03975-6

[47] Chang M, Liu Y, Zhou C, Che HX. Hazard assessment of a catastrophic mine waste debris flow of Hou Gully, Shimian, China. Engineering Geology 2020; 275: 105733. https://doi.org/10.1016/j.enggeo.2020.105733

[48] Li Y, Yang RC, Qu XY, Qu XW, Du YN, De S. Study on the risk assessment and forewarning model of groundwater pollution. Arabian Journal of Geosciences 2020; 13(11). https://doi.org/10.1007/s12517-020-05395-7

[49] Xia RY. Groundwater resources in karst area in Southern China and sustainable utilization pattern. Journal of Groundwater Science and Engineering 2016; 04: 47-55.

[50] Feng DM, Wu JW. Recognition model for mine water inrush sources based on SVM. Journal of Liaoning Technical University(Natural Science) 2017; 36(01): 23-27.
[51] Xue W. Statistical Analysis and the Applications of SPSS. China Renmin University Press. 2015.

[52] $\mathrm{Xu} \mathrm{YC,} \mathrm{Li} \mathrm{JH,} \mathrm{Liu} \mathrm{BZ.} \mathrm{Reinforcement} \mathrm{of} \mathrm{working} \mathrm{face} \mathrm{by}$ grouting in the floor in Jiaozuo mining area. Coal Geology\&Exploration 2014; 42(04): 50-54.

[53] Zhang XL, Zhang ZX, Peng SP. The application of quantification theory in identifying the sources of water bursting in mine. Journal of China University of Mining and Technology 2003; (03): 42-45.

[54] Wei WX, Han J, Shi LQ, Lu XM, Zhang XJ. The application of modern data analysis in the prediction of water bursting in mine. China Coal Industry Publishing House. 2015.

[55] Weber MC, Ward AS, Muste M. Modeling groundwater quality in an arid agricultural environment in the face of an uncertain climate: the case of Mewat District, India. Dissertations and Theses-Gradworks 2015; 1(4): 4-6.

[56] Mohammed-Aslam MA, Kondoh Mohamed RP, Manoharan AN. Evaluating groundwater potential of a hard-rock aquifer using remote sensing and geophysics. Journal of Spatial Hydrology 2010; 10(2): 76-88.

[57] Fashae OA, Tijani MN, Talabi AO, Adedeji OI. Delineation of groundwater potential zones in the crystalline basement terrain of SW-Nigeria: an integrated GIS and remote sensing approach. Applied Water Science 2014; 4: 19-38. https://doi.org/10.1007/s13201-013-0127-9

[58] Vellaikannu A, Palaniraj U, Karthikeyan S, Senapathi V, Viswanathan PM, Sekar S. Identification of potential groundwater zones using a geospatial approach in Sivagangai district, South India. Arabian Journal of Geosciences 2021; 14(1). https://doi.org/10.1007/s12517-020-06316-4

[59] Rahmani H, Naeini SA. Influence of non-plastic fine on static liquefaction and undrained monotonic behavior of sandy gravel. Engineering Geology 2020; 275: 105729.

https://doi.org/10.1016/j.enggeo.2020.105729

[60] Aravena R, Evans ML, Cherry JA. Stable isotopes of oxygen and nitrogen in source identification of nitrate from septic systems. Groundwater 1993; 31(2):180-186. https://doi.org/10.1111/j.1745-6584.1993.tb01809.x

[61] Dinka MO, Loiskandl W, Ndambuki JM. Hydrochemical charac-terization of various surface water and groundwater resources avail-able in Matahara areas, Fantalle Woreda of Oromiya region. JHydrol: Reg Stud 2015; 3:444-456. https://doi.org/10.1016/j.ejrh.2015.02.007

[62] Gao WD. Application of entropy weight Fuzzy comprehensive evaluation in identification of mine water inrush source. Mining Safety \& Environmental Protection 2012; 39(2): 22-24

[63] Gao WD, He YD, Li XS. The Application of Hydrochemical Method in Mine Water Inrush Source Judgment [Mining Safety \& Environmental Protection 2001; (10):44-45.

[64] Gong Houjian. Statistical Analysis of Coal Mine Water Hazard Accidents in China 2012-2016. Inner Mongolia coal economy 2017; (23):107-108.

[65] Huang QB, Wang YS, Liu XM. Hydrographic and geochemical characteristics and genetic analysis of Tangdou area [J]. Groundwater 2008; (6):6-8.

[66] Ian D. Clark, Peter Fritz. Environmental isotopes in hydrogeology.Zhengzhou: Yellow River Water Press 2006; P30-33.

[67] Ji XL, Xie RT, Hao Y, LuJ. Quantitative identification of nitrate pollution sources and uncertainty analysis based on dual isotope approach in an agricultural watershed. Environ Pollut 2017; 229:586-594. https://doi.org/10.1016/i.envpol.2017.06.100

[68] Ju QD, Hu YB, Zang SY. A Study on Identification Method of Mine Water Inrush Source Based on Principal Component Analysis and Bayesian Discriminating Method. Coal Engineering 2018; 50(12):90-94. 
[69] Kou WJ. Groundwater chemical classification methods of thinking.Western Resources 2012; (5): 108-109.

[70] Liu TQ. Influence of mining activities on mine rockmass and control engineering. Journal of China Coal Society 1995; (1):1-5.

[71] Meng ZP, Li GQ, Xie XT. A geological assessment method of floor water inrush risk and its application. Eng Geol 2012; 143-144:51-60. https://doi.org/10.1016/j.enggeo.2012.06.004

[72] Piper AM. A graphic procedure in the geochemical interpretation of water-analyses. Eos Transactions American Geophysical Union 1994; 25(6):27-39 https://doi.org/10.1029/TR025i006p00914

[73] Pan GY,Wang SN,Sun XY,Fang SK. Application of Isotopic Technique in Identification of Mine Water Inrush Source.Mining Safety \& Environmental Protection 2009; 36(01):32-34+90.

[74] Qu XY,Shi LQ. The Identification of Mine Water Inrush Source Based on Matlab Factor Analysis and Distance Discriminating Model,. Coal Science and Technology 2018; 46(08):178-182.

[75] Shen ZL. Hydrographic and geochemical foundations. Beijing: Geological Publishing House 1986.

[76] Song ZQ. Practical mine pressure control. Xuzhou: China University of Mining Press 1988; P50-55.

[77] Sun WY, Wu Y, Zhuo Y, T MS, He M. Hydrochemistry Characteristic of Shallow Groundwater in Enyang County,Bazhong City 2016; 16(27):114-121.

[78] Sun YJ Yang GY, Zheng L. Based on the GIS of mine water inrush source discrimination system research. Coalfield geology and exploration 2007; 35(2):34-37.

[79] Telci IT, Aral MM. Contaminant source location identi fication in river networks using water quality monitoring systems for exposure analysis. Water Qual, Expo Health 2011; 2(3):205218.

https://doi.org/10.1007/s12403-011-0039-6

[80] Tripathy DP, Ala CK. Identification of safety hazards in Indian underground coal mines. Journal of Sustainable Mining 2018; 17(4):175-I 83. https://doi.org/10.1016/j.jsm.2018.07.005

[81] W DC, Zang RQ, Shi YH. Hydrogeological fundamentals. Beijing: Geology Publishing House 1995; P61-62.

[82] Wang $\mathrm{XY}, \mathrm{Xu}$ T, Hang D. Application of distance discriminance in identifying water inrush resource in similar coalmine. Journal of China Coal Society 2011; 36(8):13541358.

[83] Wei JC, Xiao LL, Niu C. Analysis on Correlation Factors of Mine Water Hazard Accidents in China 2001-2013. China Science and Technology Paper 2015; 10(3): 336-341,369.

[84] Wu GJ. The application of Fuzzy mathematical method to evaluation of groundwater pollution. Jiangxi Geology 1999; (3): $73-78$

[85] Xu HL. Water resources development and protection. Beijing: Geological Publishing House 2001; P98-100.

[86] Xu X, Wang GZ. The Application of BP Neural Network in Identification of Mine Water inrush Source. Colliery engineering 2016; 35(7): 144-146.

[87] Xue JK. Quantitative analysis of mine water inrush using isotope method. Coal Engineering 2019; 51(12): 150-153.

[88] Yu KL, Yang YS, Zang CP. Application of Fuzzy Comprehensive Evaluation Method in Discriminating Mine Water inrush Source. Metal Mines 2007; (3):47-50.

[89] Zhang RG, Qian JZ, Ma L, Qin H. Application of extension identification method in mine water inrush source discrimination. Journal of Coal 2009; 34(1):33-38.

Received on 05-11-2020

Accepted on $30-11-2020$

Published on $10-12-2020$

DOI: https://doi.org/10.15377/2409-5710.2020.07.6

(c) 2020 Yue and Longqing; Avanti Publishers.

This is an open access article licensed under the terms of the Creative Commons Attribution Non-Commercial License (http://creativecommons.org/licenses/by-nc/3.0/) which permits unrestricted, non-commercial use, distribution and reproduction in any medium, provided the work is properly cited. 